\title{
Dynamics of Product Complexity in Africa: Structural Estimation Using Structuralists Model
}

\author{
Samson Gebresilasie Gebrerufael ${ }^{1}$
}

DOI 10.1515/JHEEC-2017-0002

\begin{abstract}
Applying the linear LAS (Latin American Structuralists) technological intensity model in Africa, this paper presents African nations are still diversifying their outputs towards the ubiquitous (fewer complexes) products. Put it simple, using the economic complexity index of Africa (explanatory variable) as a proxy for the technological intensity in Africa and per capita GDP gap (explanatory variable) as a proxy for technology gap, the paper presents a significant and positive relationship between economic complexity index of Africa and the time derivative of the economic complexity index of Africa (the explained variable). This implies that "weak" effort African nations exerted so far in diversifying their outputs towards the less ubiquitous commodities and absence of "automatic catch up tendency" (unlike what is presupposed by the mainstream neo-classical growth models). The linear panel data regression is employed on sample of 23 African economies and OECD member economies for the period 1996-2014.
\end{abstract}

Keywords:

Technology gap, technological intensity, economic complexity index, product diversification, product ubiquity

JEL Classification: $\quad$ 01, O3, F1

\section{Acknowledgment}

I thank Prof. Dr. Bart Verspagen (UNU-MERIT) for his direct and indirect comments on an earlier version of this paper.

\footnotetext{
${ }^{1} \mathrm{MSc}$ in Economic Policy Analysis, PhD Fellow at Maastricht University, UNU-MERIT, the Netherlands, Lecturer of Economics at Aksum University, Ethiopia, Postal address: Aksum University, P.O.BOX 1010, Aksum, Ethiopia Corresponding Author: Samson Gebresilasie Gebrerufael

Email: gebrerufael@merit.unu.edu or samiwedgere@yahoo.com
} 


\section{Introduction}

Understanding the increasingly large gaps in income per capita across countries is one of the eternal puzzles of development economics. Even if complexity of goods is at the root of the explanation of the large gaps in per capita income, empirical research has not advanced along these dimensions (Hidalgo and Hausman, 2009). It is also worth notice that there is no research conducted on product complexity dynamics in Africa so far. This empirical study is supposed to be done using the LAS (Latin American Structuralists) technological intensity model. Even if the LAS School is not broadly familiar to students and researchers, it is one of the significant heterodox Schools of thought that contribute to the long run growth theories (Cimoli and Porcile, 2011). Empirically testing the LAS technological intensity model could allow presenting explanatory power of the model (of the current state of Africa). Put it simple, the paper presents how the LAS technological intensity/complexity model is relevant to explain the state of African nations in terms of revealing their efforts/experiences to make their products persistently complex. Moreover, presenting product complexity dynamics in Africa could contribute to the ongoing theoretical and empirical debates (between the heterodox and the mainstream neo-classical growth models) on catch up (convergence) tendency between the North (Center) and the South (Periphery). Here the product complexity in Africa is to be studied using the technological intensity model as complexity of products is judged by how the products are intense technologically. The terms intense and complex are interchangeable as both indicate the amount of imbedded technology or knowledge in the products.

Empirically dealing with dynamics of product complexity gives more sense in poor nations (like Africa) than the advanced nations. This is because African economies could thoroughly see what is happening to their product composition and their pattern of specialization in the international market. Any failure to meet the empirically proved theoretical criteria of wellness of economies in catch up could allow stakeholder in Africa taking possible prompt remedies that could bring long run benefits in terms of lowering the international development differential. Among other things, this study could allow answering the questions: Do African nations have been diversifying their products towards more complex commodities? If not, what remedies? What is the role of technology gap for product complexity?

Given this brief introduction, the paper is organized in 6 sections. Section 2 presents state of international trade in Africa; section 3 presents literatures on trade and product complexity; section 4 presents methods; section 5 presents results and discussions and section 6 concludes.

\section{State of International Trade in Africa}

In dealing with product complexity, considering export performance of African economic sectors could roughly indicate composition of African products and their pattern of specialization. In this regard, Fuels and natural resource based products (mainly in their raw form) accounted for close to two thirds of exports in Africa. This indicates the weak role of the manufacturing sector in Africa. Apart from South Africa, the top African 
exporters are oil exporters. The often decline in merchandise exports in Africa is also attributed to the upward trend in the prices of commodities and the continued dominance of natural resource-based products. Such export swings underscore the need for African economies to diversify their production and export-base adopting value addition schemes which allows boosting export earnings (UNECA, 2015).

Empirically supporting this analysis, the share of Africa's exports in global merchandise exports is still low, declining marginally from 3.5\% in 2012 to 3.3\% 20132. Some Asian economies that were at par with African economies in the 1970s-such as Indonesia, Malaysia and Republic of South Korea increased their shares of the world trade hugely. Indeed Africa's share in global exports was higher than the East Asia region's share in 1970 and 1980. The dramatic change started around 1990 and has continued. In 1970 and 1980, Africa's share in global exports was 4.99 and $5.99 \%$, respectively. The corresponding figure for East Asia was 2.25\% and 3.74\%, respectively. In 1990, 2000 and 2010, Africa's share of global exports was 3.02\%, 2.31\% and 3.33\% respectively, compared with East Asia's share of 8.06\%, 12.02\% and 17.8\%. To make it bold, about onethird of the world trade in 2013 was by Asian countries (ibid.).

Africa exported the lowest share (18.5\%) of manufactures in the total merchandise exports in 2013. Asia had the highest share (79.1\%), followed by Europe (73.9\%) in 2013. Africa's exports are of course highly skewed towards unprocessed, natural resourcebased commodities which accounted for $68 \%$ of Africa's total merchandise exports in 2013. However, the structure of Africa's imports from the world is fairly diversified (ibid.).

With regards to trade facilitations in Africa, transaction costs ${ }^{3}$ remain among factors that impede international trade in Africa (UNECA, 2013). Six dimensions of transaction costs 4 at a regional level are considered to show the state of trade facilitation in Africa. The six dimensions of transaction costs are obtained from two different but complementary databases viz World Bank`s Doing Business Database and World Bank Trade Costs Database (ibid.). The study revealed that Africa (excluding Northern Africa) remains by far one of the two regions where international trade is most expensive (based on a six dimensions of transaction costs) ${ }^{5}$.

With regards to specialization, among the 54 African nations, only 2 nations ${ }^{6}$ have export specialization in the manufacturing sector. However, $57.4 \%$ of the 54 nations in Africa have export specialization in non-manufacturing goods and services ${ }^{7}$. The rest $38.8 \%$ of African nations (11 nations) have export specialization in mixed sectors (UNCTAD, 2015).

\footnotetext{
2 It was 4.9 per cent in 1970 s.

3 Transaction cost refers to time and monetary costs related to international trade.

4 The six dimensions of the transaction costs are number of documents to export, number of days to export, cost per container to export, number of documents to import, number of days to export and cost per container to import.

${ }^{5}$ See (UNECA, 2013) for a detailed analysis of the six dimensions.

6 The only two nations which have export specialization in manufacturing sector are Lesotho and Tunisia.

7 Export specializations in non-manufacturing sector constitute export specialization in food and agriculture (4 nations), fuel (10 nations), ores and metals ( 6 nations) and services (11 nations). The service exports are travel, transportation and other services.
} 
Given these weakness of the manufacturing sector in Africa, the service sector in Africa constitutes the largest segment of the economy. Put it simple, during the period 20002012, the service sector contributed an increasing share to gross domestic product (GDP), trade and employment (ibid.).

\section{Trade and Product Complexity Literatures}

Based on Krugman (1979), trade is associated with exploitation of scale economies under condition of increasing returns to scale ${ }^{8}$. By scale economies he refers to extending the market. This view of trade seems important to understand trade among the industrial countries (ibid.). Unlike the classical trade theories, the model of Krugman explains general equilibrium under non-comparative advantage (ibid.) ${ }^{9}$.

Product level U.S. trade data indicates empirical finding against trade models that advocate endowment driven specialization across products (Skchott, 2003). The data also indicates a positive relationship between product price and exporters endowment ${ }^{10}$. Based on the new trade theories, what was expected is a negative relationship between product price and productivity (ibid.). The new trade theories suggest this negative relationship based on the assumption that skill and capital abundant countries enjoy relatively high productivity which allows them to sell their goods at a discount relative to the price of the goods from labor abundant countries. However, the U.S. data indicates against the new trade theories (ibid.). The positive relationship suggests that high wage countries use their endowment advantage to add features or quality to their varieties which allow them charge higher prices for their varieties (ibid.).

Large economies export more (in absolute/unconditional term) than small economies (Hummels and Klenow, 2005). Given this, they examine the extent to which large economies export higher volume of each good (the intensive margin), export a wider set of goods (the extensive margin) and export higher quality goods using the 1995 trade data of 126 exporting countries and 59 importing countries. The extensive margin accounts for $60 \%$ of the greater exporters of large economies (ibid.). This finding suggests product diversification is an inherent behavior of advanced economies.

Within the different categories of products ${ }^{11}$, advanced nations export prices are found to be moderately higher (ibid.). This finding could also suggest that the diversification is towards more quality products to the extent the new products get acceptance internationally.

\footnotetext{
${ }^{8}$ Unlike other trade models, economies of scale are assumed to be internal to the firm. The model of Krugman also assume the Chamberlinian monopolistic completion market in which firms have some monopoly power due to product differentiation.

9 The classical's model of trade recognize difference in technology or factor endowment as an explanation of international specialization and trade.

${ }^{10}$ Exporter's endowment refers to capital and skill abundance and production techniques.

11 There are 5000 product categories.
} 
The finding is consistent with the work of Haussmann and Hidalgo (Haussmann and Hidalgo, 2010). There is a systematic relationship between the diversification of a country`s export and the ubiquity of its products (ibid.). They provide this "stylized fact" constructing a model that assumes that each product requires a potentially large number of complementary non-tradable inputs ${ }^{12}$. Given these non-tradable capabilities, a country can only make the product for which it has all the requisite capabilities (ibid.). Simply put, if the country misses some of these capabilities, there is no way to produce the product ${ }^{13}$.

Products that require more capabilities will be acceptable to fewer countries (less ubiquitous) and countries that have more capabilities could produce more new products or diversify their products (ibid.). This suggests African products are more ubiquitous and African exports are less diversified.

Moreover, there is positive convex ${ }^{14}$ relationship between the increase in diversification and accumulation of new capabilities (ibid.). They relate this convexity with a quiescence trap (economic stasis). The quiescence trap refers to countries with few capabilities will have negligible or no return to the accumulation of more capabilities and vice versa (ibid.). This is because, since countries with few capabilities are far from the knowledge frontier coming one step closer to the knowledge frontier might not automatically impact production of new product. Simply put, our world exists in a regime where quiescence trap is strong in which capabilities gap is getting wider (ibid.).

Meltz(2003) suggests that the exposure to trade will induce only the more productive firms to enter the export market while the less productive firms continue to produce only for the domestic market which helps to maintain existence of the least productive firms. This implies, unlike Haussmann and Hidalgo, accumulation of capabilities by less capable nations might be crucial as long as the accumulation of the capabilities help them produce and meet pockets of local demands. If the efforts of meeting local demand via imitation (in fact imperfectly copy initially) persist, there might be a room to produce for international markets in the long run ${ }^{15}$.

The reason why firms with different productivity coexist in an industry is that each firm faces initial uncertainty concerning productivity of the new product. This is because the decision requires irreversible investment to enter the industry and entry into the export market is also costly as acceptability of the product is not fully known in the outset (ibid.) ${ }^{16}$.

Economies of externalities associated with clustering are permanent if "proper" policy is put in place. If clustering externalities expected to be are that of Marshallian externalities (intra-industry externalities), applying policies that promote high tech against the natural (existing) comparative advantage does not give sense (Rodriguez, 2007). However, if inter-industry or economy wide externalities are targeted, having policies against the

\footnotetext{
12 The non-tradable inputs are capabilities.

13 Since the capabilities are complementary.

14 Knowledge accumulation grows exponentially with product diversification.

15 via learning by doing.

${ }^{16}$ Long run benefits are expected in association with trade induced reallocation within an industry.
} 
natural comparative advantages could give sense (ibid.). This is because the losses from going against the natural comparative advantage by specializing in the new sector are small (ibid.).

Marshallian externalities arise when firms switch to apply more modern technologies to their production process. The modern technologies are characterized by heavy reliance on large variety of specialized inputs and constant flow of innovations ${ }^{17}$ (ibid.). The policies one could apply to make sure that the modern that the modern technologies are accessible to firms are reducing transaction costs, promotion of domestic production of "certain key inputs", R\&D incentives in the form of tax breaks and matching grants for innovation projects (ibid.). Reducing the transaction costs of getting the modern inputs would enhance willingness of firms to use the modern technologies (ibid.).

From institutional economics perspective, the adverse impact of contractual incompleteness on technology adoption and productivity are greater in sectors that use more complementary intermediate inputs (Acemoglu, Antras \& Helpman, 2006) ${ }^{18}$.This suggestion is consistent with the work of Haussmann and Hidalgo (2010) ${ }^{19}$.

Under the 0-ring production function of Kremer, small differences in worker skill leads to large differences in wage and output. This implies that countries with higher skill will have higher wage and productivity and vice versa (Kremer, 1993). In other words, workers are sorted by quality and therefore there is positive correlation between the wage of workers and quality of workers with in a firm.

At macro level, if tasks are performed sequentially, high skill workers will be allocated to later stage of production. Since poor countries have higher share of primary products in GNP (which are products of early stage of production), workers on poor countries will be paid less and vice versa (ibid.).

From technology point of view, firms with highest skill workers will use the highest possible technology. This leads us to suggest rich countries specialize in more complicated products (ibid.).

Based on Weitzman`s (1998) model of firm level knowledge production, new knowledge production is a function of newly reconfigured old ideas. This implies that countries with highest capabilities would have greater possibilities to innovate and specialize towards more complicated products than poor countries with lower capabilities.

The greatest improvement in the productive power of labor (both physical skill and mental skill) is the effects of the division of labor (Smith, 1776). Since greater chance of

\footnotetext{
17 This will be realized via high R\&D investment rate.

18 Technology is defined as the range of inputs used by firms which are supposed to increase productivity due to specialization.

${ }^{19}$ Haussmann and Hidalgo state that all the complementary capabilities (non-tradable inputs) must be there to produce the new goods.
} 
division of labor is found in the manufacturing sector than the agricultural sector, countries with advanced manufacturing sector have much better capabilities than the agrarian economies. This in turn helps rich nations to specialize towards more complicated products.

Nations grow by upgrading the type of products they produce and export. Upgrading basically tied to the previous level of capabilities (Hidalgo et al., 2007). They also indicated that countries diversify their products towards goods close to the current products. Based on this we could suggest agrarian economies diversify towards some other agricultural outputs in their efforts to exploit their natural resources. On the other hands, unlike the poor nations, the new close product for rich nations is a more complicated product which requires more capabilities than the existing level of capabilities. Thus, advanced nations are in continuous improvement in their capabilities than the poor nations.

To make catch up realized in the south, the south needs to "jump" over infrequent distance in the product space. Inability of the south to "jump" is suggested to be caused by producing non competitive export and failing to converge to the income level of the rich nations (ibid.). With regards to the network of relatedness between products or product space, the most upscale/advanced products are located in densely connected core and lower income products located in less connected periphery/south (ibid.).

Unlike recent theories that assume homogeneous ${ }^{20}$ and continuous product space, the product space is empirically found to be heterogeneous (Haussmann and Klinger, 2006). The implication of product space heterogeneity could be in terms of adversely affecting the speed at which nations can transform their productive structure and improve their exports. That is speed of transformation mainly depends on having a close product that have higher value. Since nations vary with product closeness, growth performances of nations differ across the world (ibid.). In other words, nations that currently producing a close products to the highly valued products could transform their productive structure faster than nations that lack it.

The problem associated with having a less closed products is that the nations specialized in goods that require assets and skills or capabilities that are very specific to the products they are producing ${ }^{21}$. Specializing in products like oil production, tropical products and other raw materials (open forest) could be examples that prevent nations from diversifying their products to the more advanced level ${ }^{22}$ (ibid.). However, engaging in light manufacturing, electronics and capital goods production require skills and assets that are much closer to those required by other goods and hence facilitate the transformation of the productive structure (ibid.).

Based on empirical study conducted on 180 developing and developed countries, episodes during which economic growth decelerate to negative rate are strongly

\footnotetext{
20 The assumption of homogenous product space is based on the fact that developing countries have a room to imitate goods invented in developed countries.

${ }^{21}$ Very specific capabilities for a given activities hinder the chance to move towards different new products as the existing capabilities are specific to the existing activities only.

22 These products require very specific endowments.
} 
associated with the change in the level of export (Hausman et al., 2006). More precisely, their finding indicate that, a one standard deviation decrease in the growth rate merchandise export results in a 5.47 percentage points increase in the productivity of a crises or economic growth deceleration.

Among other factors, structural change played a positive significant role in economic development efforts of OECD countries (Saviotti and Frenken, 2006). The structural change in OECD nations is basically related to the increase in export varieties and the associated productivity growth for the period 1961-2003 (ibid.).

Even if the positive role of export varieties on GDP per capita is known, its role varies across time periods (Saviotti, Nesta and Javid, 2010). In other words, the role of export varieties on per capita GDP growth (in terms of significance) is more for the period 19801999 than the period 1961-1999 (ibid.). This implies the recent period role of export varieties on per capita GDP growth is more significant than the previous period as the recent period export items are more complex. The complexity of recent export goods is the result of higher attention given to R\&D intensity and innovations (ibid.). Catch up by imitation is restricted by time periods (Fagerberg and Godinho, 2004, Fagerberg and Verspagen, 2002 and Fagerberg and Shrolec, 2008). While the period 1960-1980 gave chance to imitation and catch up, from the year 1980 onward imitation has no room to facilitate the catch up tendency. The option at hand therefore is to create nation specific innovation system to be successful in the catching up efforts (ibid.). In other words, nations should innovate to be competitive in the highly competitive international export markets (Saviotti, Nesta, and Javid, 2010).

The technology gap theorists of the neo-technological tradition such as Kravis (1956), Posner (1961), Vernon (1966) and Hirsch (1967) relate the technology level to its level of innovative activities. A high level of the innovative activity of a nation is manifested by the share of new goods in output and the new input and a new technique employed in the production process (ibid.). The rationale for this explanation is new goods bring higher returns and the new technique enhances the level of productivity. This argument would lead us to the conclusion that countries with a relatively higher level of innovative activities could have higher level of GDP per capita than those nations that have lower level of it (ibid.).

\section{Methods}

\subsection{Data}

This study employs secondary data from World Bank`s database (WDI database, Feb, 2016) and the OEC (the Observatory of Economic Complexity) database provided by Simoes \& Hidalgo (Simoes \& Hidalgo, 2011). The variable taken from the WDI database is per capita GDP (at market price in constant 2005 USD) for both the OECD member economies and each sample African economies (for the 23 sample African economies) for 
the period 1996-2014. The variable taken from the OEC database is the economic complexity index (eci) of the sample African economies for the same period (1996-2014).

\subsection{Regression Method}

The econometrics part of this study is analyzed employing the standard linear panel data regression method. The panel data regression is supposed to be relevant for this paper for it helps analyzing dynamics of products complexity across the sample African nations over time.

Based on Wooldridge (2011) and Guajarati (2004), the typical linear panel data regression methods are the fixed effects (FE) and the random effects (RE) regression methods. Following Wooldridge (2011) again, applying the pooled OLS on panel data makes the OLS estimators to be biased and inconsistent. This is mainly because pooled OLS is assumed to suffer from time-constant unobserved effects that can vary with explanatory variables and therefore endogenity. However, the two standard linear panel data regression methods (viz FE and RE) can control the estimation problems of the pooled OLS method. Since the FE and RE are not generally interchangeable, comparing their drawbacks and choosing one of them (using Hausman specification test) is the job done in this paper.

\subsection{The Model}

This paper uses the linear LAS technological intensity model to illustrate how the African products have been diversifying over the last two decades. The specification of the linear LAS technological intensity model will be presented based on the structuralists toolbox provided by Cimoli and Porcile (Cimoli and Porcile, 2011).

Hence, the dynamics of the linear LAS technological intensity model in South is represented as follows:

$N=e_{c i}$

Where $\mathrm{N}=$ technological intensity of the South, $\mathrm{e}_{\mathrm{ci}}=$ economic complexity index of the South.

In equation (1), the economic complexity index $\left(\mathrm{e}_{\mathrm{ci}}\right)$ is considered as proxy for technological intensity or product complexity of the South. As it is already stated, the Economic complexity index, which is a proxy for technological intensity in the South, is provided by Simoes \& Hidalgo, 2011. Since economic complexity of a nation is supposed to be correlated with product complexity of the nation, taking either economic complexity index ECI) or product complexity index (PCI) could allow us understanding technological intensity of nations. In other words, it is presented that the complexity of an economy is proportional to the average complexity of its products and vice versa (Hausman and Hidalgo, 2009).

Based on the model, the higher the value of the economic complexity index implies that the more the products of the nation getting complex or intense technologically and therefore the higher the level of growth. The same is argued by Haussmann and Klinger (2006). The economic complexity index (of Simoes \& Hidalgo) is provided based on two 
concepts viz a number of products a nation have been exporting (product diversification) and a number of other nations that are producing the products (product ubiquity). The more the diversification and the less ubiquity of the products, the more the economic complexity index of a nation will be. High-tech products producing economies are generally stated as producers of more diversified and less ubiquitous products ${ }^{23}$.

Taking time derivative (the change over time) of equation (1), it will be:

$$
\dot{N}=\frac{d N}{d t}=\frac{d e_{c i}}{d t}=\dot{e}_{c i}
$$

Equation (2) is the time derivative of economic complexity index ( $\mathrm{e}_{\mathrm{ci}}$ ). The positive time derivative of $e_{c i}$ implies that the commodities in the South are getting more complex and vice versa.

Give this definition of time derivative of the economic complexity index, the next concern will be to present the LAS theoretical variables that could potentially influence the technological intensity of the products in South. To present these variables, it will be good idea to consider the concepts of relative labor productivity and relative wage rate in the South along with what determine both as they are supposed to determine whether the goods in question are to be produced in the South or in the North.

Hence, the relative labor productivity of the South is specified as:

$\pi=\frac{\pi s}{\pi n}$

Where $\pi_{\mathrm{s}}=$ labor productivity in the South, $\pi_{\mathrm{n}}=$ labor productivity in the North, $\pi=$ relative labor productivity in South.

The relative wage rate in the South is also specified as:

$w=\frac{W_{s}}{w_{n} * e}$

Where $\mathrm{w}_{\mathrm{s}}=$ nominal wage rate in the South, $\mathrm{w}_{\mathrm{n}} \mathrm{e}=\mathrm{n}$ nominal wage rate in the North, $\mathrm{e}=$ exchange rate (dimension: South currency/ North currency) and $\mathrm{w}=$ relative wage rate in South. As it is known the exchange rate allows having a common unit of measurement (currency) for both the South and the North.

Given equation (1) and (2), criterion for any given output to be produced in the South is:

$$
\frac{W_{s}}{\pi s} \leq \frac{W_{n}^{*} e}{\pi_{n}}
$$

\footnotetext{
23 The economic complexity indexes of advanced nations are also relatively higher positive values while that of most of African nations are negative values. In this study except South Africa, all sample African nations have negative economic complexity indexes which indicate their complexity indexes are lower than the average complexity index of all nations. Based on (Hausman and Hidalgo, 2009), economic complexity index is given by: $E C I_{i}=\frac{c_{i}-\langle c\rangle}{s t d\langle c\rangle}$, where $c_{i}$ is each country`s economic complexity index and $\langle c\rangle$ is average economic complexity index of all countries. So that the value of $\operatorname{ECI}_{\mathrm{i}}=(\infty,-\infty)$.
} 
Equation (5) implies that the output will be produced in the South if ratio of wage to average product of labor in South of a typical output is at least equal to ratio of wage to the same average product of labor in the North ${ }^{24}$. It is obvious that higher ratio implies higher cost of production and vice versa. Thus, having lower cost of production in the South (relative to the North) makes the product more likely to be produced in the South. Rearranging ${ }^{25}$ equation (5), we will have the following equation which gives the same implication as the equation (5) implies.

$$
\frac{\pi s}{\pi n} \geq \frac{W_{s}}{W_{n}{ }^{*} e}
$$

Equation (6) implies that a product will be produced in the South if the relative labor productivity in the South at least equal to the labor productivity in the North.

$$
\frac{\pi s}{\pi}=\pi i
$$

Let, $\pi_{n}$, which implies relative labor productivity of the South of commodity i.

Let again, $\frac{\boldsymbol{W}_{\boldsymbol{s}}}{\boldsymbol{W}_{\boldsymbol{n}}{ }^{*} \boldsymbol{e}}=\boldsymbol{W}_{\boldsymbol{i}}$, which implies relative nominal wage of commodity i of the South. Then, equation (4) could be rewritten as:

$$
\pi_{i} \geq \boldsymbol{W}_{i}
$$

Now equation (7) implies that, commodity "i" will be produced in the South in case relative labor productivity of the commodity in the South is at least equal to the relative nominal wage of the South. What determine $\pi_{\mathrm{i}}$ ?

Based on the LAS toolbox, $\pi_{\mathrm{i}}$ depend on technology gap (technological capabilities) and technological intensity (technological complexity). The higher the North-South technology gap, the lower the relative labor productivity of the South for all goods as labor productivity is directly related with technological capabilities (stock of knowledge). Likewise, the higher the level of the product's technological complexity for the South, the lower the level of the relative labor productivity in the South and therefore the product will not be produced in the South (based on equation 7). These arguments imply both technological intensity and technology gap adversely affect relative labor productivity in the South. Symbolically:

$$
\pi_{i}=\alpha+\beta \mathbf{N}+\theta \boldsymbol{G}
$$

From equation (8), $G=$ technology gap, $\alpha>0$, and $\beta$ and $\theta$ are parameters which are constrained to be negative. $\mathrm{N}$ is order of goods based on technological intensity. That is $\mathrm{N}=\mathrm{N}_{1}, \mathrm{~N}_{2}, \ldots, \mathrm{N}_{\mathrm{m}}$ and $\mathrm{N}_{1}$ is the product with least technologically intensive (or $\mathrm{N}_{1}$ is the least technologically intense/complex good which implies the good could have lower export demand and require the least technological capabilities to produce it). For instance, as one move from production of $\mathrm{N}_{1}$ to $\mathrm{N}_{2}$, the product $\mathrm{N}_{2}$ is technologically intense (relatively

$24 \mathrm{Ws} / \pi \mathrm{s}$ is ratio of wage to average product of labor in South.

${ }_{25} \frac{W_{s}}{\pi_{s}} \leq \frac{W_{n} * e}{\pi_{n}} \rightarrow \frac{\pi_{s}}{W_{s}} \geq \frac{\pi_{n}}{W_{n} * e} \rightarrow \frac{\pi_{s}}{\pi_{n}} \geq \frac{W_{s}}{W_{n} * e}$ 
more advanced) than $\mathrm{N}_{1}$. In other words, the diversification of outputs is towards the less ubiquitous products.

Having defined the concept of technological intensity of the product, the next job will be defining the technology gap. The technology gap is stated as:

$$
G=\ln \left(\frac{T_{n}}{T_{s}}\right)
$$

Where $\mathrm{T}_{\mathrm{n}}=$ technology in the North (per capita GDP in the North is proxy for $\mathrm{T}_{\mathrm{n}}$ ), $\mathrm{T}_{\mathrm{s}}=$ technology in the South (per capita GDP in the South is proxy for $\mathrm{T}_{\mathrm{s}}$ ).

At this point it is already defined the determinants of the relative labor productivity in the South or $\pi_{\mathrm{i}}$ (stated in equation 8 ) based on the LAS toolbox. To make the analysis plausible it will be good idea to define what determine the relative nominal wage in the South as the production decision depends on the size of relative labor productivity $\left(\pi_{i}\right)$ and relative nominal wage $\left(\mathrm{W}_{\mathrm{i}}\right)$ in South (based on equation 7).

Therefore, based on the LAS toolbox, $\mathrm{W}_{\mathrm{i}}$ depends on the relative economic growth of the South. This is due to the argument that the higher the relative growth of the South, the higher the demand for labor and therefore the higher the nominal wage will be and vice versa. Moreover, the higher the relative growth, the higher the relative labor productivity will be and therefore the higher the nominal wage and vice versa. In both ways, there is a positive relationship between relative growth and nominal wage in the South. Symbolically stating these arguments:

$$
\boldsymbol{W}_{\boldsymbol{i}}=\phi \boldsymbol{y}
$$

where, $y=y_{s} / y_{n}$ (or relative growth in the South) ${ }^{26}$ and $\phi$ is parameter constrained to be positive.

Given equation 3 to 10, the time derivative of the technological intensity of the South $(\dot{N})$ positively depends on the difference between the relative labor productivity of the South and the relative nominal wage of the South as this determine the chance to produce a product in the South (based on equation 7). This could be symbolically stated as:

$\dot{N}=\lambda\left(\pi_{i}-W_{i}\right)$

- Where $\lambda$ is a parameter constrained to be positive $(\lambda>0)$.

Equation (11) implies that the higher the value of the relative labor productivity of the South above the relative nominal wage of the South, more complex products could be produced in the South and therefore technological intensity of the South improves (positively change) and vice versa.

Substituting equation (8) and equation (10) into equation (11):

$\dot{\boldsymbol{N}}=\lambda(\alpha+\beta \boldsymbol{N}+\theta \boldsymbol{G}-\phi \boldsymbol{y})$

$\dot{\boldsymbol{N}}=\lambda(\alpha+\boldsymbol{\theta} \boldsymbol{G}+\beta \boldsymbol{N}-\boldsymbol{\phi} \boldsymbol{y})$, rearranging terms in the bracket

Equation (12) implies that the time derivative of technological intensity of the South negatively depends on technology gap (G), technological intensity of the South $(\mathrm{N})$ and relative growth (y) in the South (since $\lambda>0, \theta<0, \beta<0$ and $\phi>0$ ).

\footnotetext{
${ }^{26} \mathrm{y}_{\mathrm{s}}=$ growth in South; $\mathrm{y}_{\mathrm{n}}=$ growth in North
} 
Now, let's define what determine the relative growth rate of the South (y). Based on the LAS toolbox again, the relative economic growth in the South(y) is a positive function of technological complexity $(\mathrm{N})$ in the South. This implies that the more the nations able to produce the more technologically complex commodities, the higher the income elasticity ratio of the South will be.

The higher this income elasticity ratio, the higher the growth rate will be in the South (Thirlwall, 2011) ${ }^{27}$. Symbolically expressing these arguments:

$\boldsymbol{y}=\psi \boldsymbol{N}$, where $\Psi>0$

Substituting equation (13) into equation (12):

$$
\begin{aligned}
& \dot{\boldsymbol{N}}=\lambda(\alpha+\boldsymbol{\theta} \boldsymbol{G}+\beta \boldsymbol{N}-\boldsymbol{\phi} \psi \boldsymbol{N}) \\
& \dot{\boldsymbol{N}}=\lambda(\alpha+\boldsymbol{\theta} \boldsymbol{G}+(\beta-\phi \psi) \boldsymbol{N})
\end{aligned}
$$

Equation (14) says the time derivative of technological intensity is a negative function of technology gap and technological intensity. The equation is theoretically a stable differential equation as stability requires coefficient of $N$ to be negative (since $\theta<0, \beta<0$, $\phi>0$ and $\Psi>0$ ). The negative coefficients of $\mathrm{N}$ and $\mathrm{G}$ imply that the higher the technological intensity and technology gap of the South, the more the adverse effects they will have on the change in the technological intensity of the South. More importantly, if the relationship between the change in the technological intensity of the South and the technological intensity of the South is found to be negative, it implies that the South features more and more difficulties in diversifying their products towards the less ubiquitous ones. However, if this condition is absent (if positive relationship between the explained and explanatory variables exists), it indicates that the South is diversifying towards the ubiquitous products.

Following Hausman and Rodrik (2003), this negative relationship might be due to higher entry costs of producing the more technologically advanced commodities. The higher entry costs in turn might be the result of costs associated with generating market information, building a reputation in the existing or new markets and cost of processes of acquiring, mastering and adopting the new know how, ceteris paribus (ibid.). These might adversely affect the relative income elasticity ratio of the South.

From equation (14), the equilibrium level of technological intensity (N) could be arrived at when the time derivative of technological intensity is equal to zero $(\dot{N}=0)$. The time derivative of the technological intensity is tending towards zero (following the increase in $\mathrm{N}$ ) means that the products of the South are being diversified towards the less ubiquitous ones (as it is already stated). Solving equation (14) for $\mathrm{N}$ when the level of $(\dot{N}=0)$ provides the equilibrium level of $\mathrm{N}$. That is:

$$
\mathbf{N}=\frac{-(\alpha+\theta \boldsymbol{G})}{\beta-\phi \psi}
$$

From equation (15), the value of $\mathrm{N}$ is equilibrium level of $\mathrm{N}$ that makes $\dot{N}=0$ (since $\alpha>0, \theta<0, \beta<0, \phi>0$ and $\Psi>0$ ). From this, the equilibrium level of $\mathrm{N}$ keeping on declining as technology gap (G) keeps on increasing. This implies that, the higher the level of the technology gap, it will be difficult to imitate advanced nations products in the South and

\footnotetext{
${ }^{27}$ Thirlwall`s law of BOP constrained growth (Thirlwall, 2011) presents the long run economic growth is approximately equal to the ratio of income elasticities $\left(\varepsilon_{\mathrm{x}} / \varepsilon_{\mathrm{m}}\right)$ or ratio of income elasticity of export to income elasticity of import; where $\varepsilon_{\mathrm{x}}$ and $\varepsilon_{\mathrm{m}}$ are income elasticity of export and import respectively.
} 
therefore growth retarding as the pattern of specialization adversely affected. It is worth notice that technology gap is blessing in case nations have "capabilities" to successfully imitate (benefit from technology spillovers) and boost their economy and vice versa.

Based on equations (14 and 15), the theoretically stable differential equation of the LAS technological intensity model could be presented using the following phase diagrams.

Figure 1: Phase Diagrams of the Linear LAS Technological Intensity Model

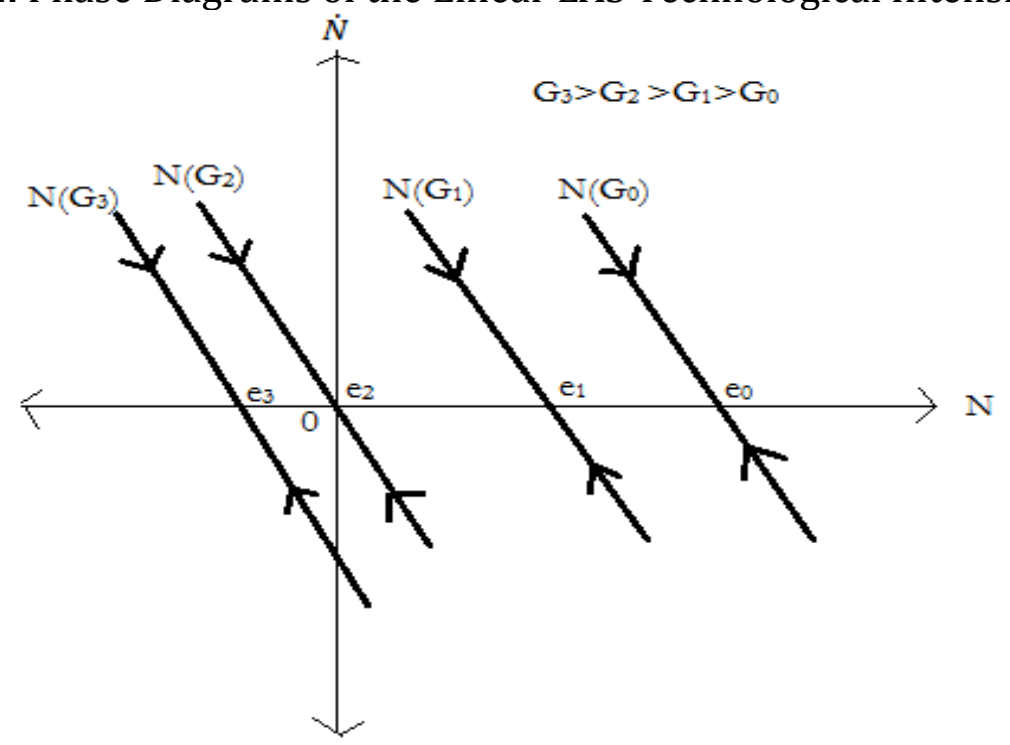

Source: Own illustration based on the LAS technological intensity model (equation $14 \& 15$ )

From the phase diagrams (Figure 1), the equilibrium points of the technological intensities are represented by $\mathrm{e}_{0}, \mathrm{e}_{1}, \mathrm{e}_{2}$ and $\mathrm{e}_{3}$ on the phase diagrams $\mathrm{N}\left(\mathrm{G}_{0}\right), \mathrm{N}\left(\mathrm{G}_{1}\right), \mathrm{N}\left(\mathrm{G}_{2}\right)$ and $N\left(G_{3}\right)$ respectively. The higher the level of the technology gap, the lower the technological intensity of the South will $b^{28}$ and vice versa. This is presented by the movement from point $\mathrm{e}_{0}$ to $\mathrm{e}_{3}$. Points like $\mathrm{e}_{3}$ are the terrible points where technological intensity is negative (as it represents the product complexity index of the respective nation is below the world average which belongs to behavior of most African economies). Finally since we are going to deal with dynamics of technological intensity in more than one nations, panel data regression form of equation (14) will be:

$$
\dot{\boldsymbol{N}}_{i t}=\lambda\left(\alpha-\theta \boldsymbol{G}_{i t}-(\beta+\phi \psi) \boldsymbol{N}_{i t}\right)+\boldsymbol{L}_{i t}
$$

Where, $\dot{N}_{i t}$ is the time derivative of the technological intensity of nation "i" (in South) at time $\mathrm{t}$; $\mathrm{G}_{\text {it }}$ is technology gap of the nation $\mathrm{i}$ (in South) at time $\mathrm{t}$; $\mathrm{N}_{\mathrm{it}}$ is technological intensity of the nation " $\mathrm{i}$ " (in South) at time $t$ and $\mathrm{u}_{\mathrm{it}}$ is the error term.

Equation (16) implies that the time derivative of the technological intensity of a nation in the South negatively depends on the technology gap and technological intensity of the

${ }^{28} \mathrm{G}_{3}>\mathrm{G}_{2}>\mathrm{G}_{1}>\mathrm{G}_{0}$ 
South itself ${ }^{29}$. The declining trend of $N$ following successive higher values of $\mathrm{N}$ implies that economies move to-wards equilibrium under normal condition (stable differential equation).

Therefore, based on the aforementioned theoretical analysis, the following two research hypotheses are going to be tested in this paper:

i. Per capita GDP gap (proxy for technology gap) negatively affects the time derivative of the economic complexity index (proxy for technological intensity).

ii. Economic complexity index (eci) negatively affects the time derivative of the economic complexity index.

\subsection{Diagnostic Tests}

Once we know the econometrics regression methods to be applied in this paper, the next question will be the way to choose between estimation results of the FE and RE. The estimation result is chosen based on Hausman specification test. The key consideration in choosing between the RE and FE estimation results is whether the unobserved effects correlated with explanatory variables or not.

Hausman (1978) proposed a test based on the difference between the random effects and fixed effects estimates. When unobserved effects correlated with explanatory variables, FE estimators are consistent (as they are free from endogenity) but RE estimators are inconsistent.

Based on Hausman specification test, statistically significant difference between FE and $\mathrm{RE}$ estimates is interpreted as evidence against the random effects assumption and therefore the correctly specified model is FE. In other words, a significant Hausman test implies existence of omitted variable that could have associated with explanatory variables and the correctly specified model will be the fixed effects model as it eliminates the problem via transformation. In contrast, statistically insignificant difference between $\mathrm{FE}$ and RE estimates is interpreted as evidence in favor of the RE assumption and therefore the correctly specified model is RE model.

Therefore, estimates of the FE regression result would be relevant in case the Hausman specification test is significant as they are supposed to be consistent estimates and vice versa (Hausman, 1978). In other words, if the Hausman specification test is insignificant, the estimates of the RE regression result are relevant and therefore Breusch and Pagan Lagrangian multiplier test will be consulted for possible heteroscedasticity in the data set. However, since the Hausman specification test of this study is found to be in favor of the FE estimates, no Breusch and Pagan Lagrangian multiplier test is conducted.

Finally to test the possible autocorrelation in the panel data, Wooldridge Test will be conducted. Significant value of the F-statistics (of Wooldridge Test) implies that presence

\footnotetext{
${ }^{29}$ Based on FE panel data method, coefficients of equation (15) indicate deviation of the explained variable (change in the technological intensity) of a nation from the mean technological intensity change due to a unit (or a one percentage point) deviation of an explanatory variable from its own mean. Moreover, the estimators are fixed effect estimators (within estimators) as the OLS based on fixed effect panel data method uses the time variations in explained and explanatory variables within each cross-sectional observations.
} 
of first order autocorrelation in the data set as the null hypothesis of the test represents "no first order autocorrelation". The possible remedy one can use to act against the maleffects of the first order autocorrelation in a data set is to have the robust standard errors of Driscoll-Kraay. The robust standard errors of Driscoll-Kraay could be used in case the Hausman specification test is in favor of the FE estimates. Therefore, since Hausman specification test of this study is in favor of the FE estimates, the FE regression with robust standard errors of Driscoll-Kraay will be run to control the mal-effects of the first order autocorrelation observed in the data set.

\section{Results and Discussions}

Just to remind the variables and sample economies once again, the three variables of the LAS technological intensity model are the time derivative of the technological intensity of Africa (the explained variable), technological intensity of Africa and the technology gap (the explanatory variables). Proxy variables for the technological intensity and technology gap are economic complexity index of Africa and the per capita GDP gap (logarithm of ratio of per capita GDP of OECD to per capital GDP of each sample African nations) respectively.

With regards to the sample economies, sample of 23 African nations ${ }^{30}$ and OECD member nations are taken based on availability of data (particularly the availability of economic complexity index of the sample African nations) for the period 1996-2014.

It is also good idea to have a look at the preliminary tests viz the Hausman specification test and the Wooldridge test for autocorrelation before presenting the regression results. The Hausman specification test (table 4 under appendix) is found to be significant which indicates evidence in favor of accepting the estimates of the FE regression result. The Wooldridge test for autocorrelation ${ }^{31}$ in panel data shows presence of first order autocorrelation in the data set as the $\mathrm{F}$ value is found to be significant at less than $1 \%$ level of significance. To correct for the potential misleading conclusions with the presence of autocorrelation, the FE regression with Driscoll-Kraay robust standard errors is employed.

Given these preliminary tests, the next task will be to present estimates of the FE regression results with the Driscoll-Kraay ${ }^{32}$ robust standard errors.

Table 1: FE Regression Result (with the Robust Driscoll-Kraay standard errors)

\begin{tabular}{|l|l|l|l|l|}
\hline The variables and the constant & Coefficients & $\begin{array}{l}\text { t-value } \\
\text { (robust SE) }\end{array}$ & P-value & Significance \\
& & & & \\
\hline
\end{tabular}

\footnotetext{
30 see table 9 (under appendix)

${ }^{31}$ see table 5 (under appendix)

${ }^{32}$ see table 6 (under appendix)
} 


\begin{tabular}{|l|l|l|l|l|}
\hline $\mathrm{e}_{\mathrm{ci}}$ & 0.4344577 & 8.57 & 0.000 & $* * *$ \\
\hline $\mathrm{g}$ & 0.0100955 & 0.12 & 0.904 & - \\
\hline _cons & 0.3754865 & 1.21 & 0.238 & - \\
\hline
\end{tabular}

*** indicates level of significance at less than $1 \%$

$\mathrm{e}_{\mathrm{ci}}=$ economic complexity index of sample African nations.

$\mathrm{g}=$ per capita GDP gap (in logarithm)

Source: Based on WDI and OEC databases for the period 1996-2014.

From table (1), the expected sign of the coefficients of the explanatory variables viz the coefficients of "eci" (economic complexity index) and "g" (per capita GDP gap) are found to be positive which is against the theory of the LAS technological intensity model (under normal condition). In other words, unlike these empirical findings, the LAS technological intensity model predicts that the per capita GDP gap (proxy for technology gap) and the economic complexity index (proxy for technological intensity) to have negative influences on the time derivative of the economic complexity index of the South. This is based on the idea that technology gap and product complexity make labor productivity lower in the South and therefore a gradually falling time derivative of the product complexity in the South.

With regards to the statistical significance only economic complexity index (eci) is found to be significant at less than $1 \%$ level of significance. This positive and significant effect of the economic complexity index could imply that African nations are diversifying their products towards technologically less intensive, familiar but ubiquitous commodities. It is worth notice that, these familiar commodities could be different in kind but might not command more advanced capabilities or (might not challenge the relative labor productivity of Africa). Commodities like these might be specialization towards different agricultural outputs, services or natural resources which were not previously known to the respective areas (or launch to produce and export commodities which were not meant for export previously). This explanation seems consistent with the report of UNCTAD (2015). Based on the report, export specialization in the manufacturing sector in Africa seems to be at its lowest state. Among the 54 African nations only 2 nations $(3.7 \%$ of the 54 African nations) have export specialization in the manufacturing sector in Africa. However, $57.4 \%$ of the 54 nations in Africa have export specialization in nonmanufacturing goods and services. The rest 38.8\% of African nations (11 nations) have export specialization in mixed sectors (ibid.). The service sector in Africa is also constitutes the largest segment of the economy. More precisely, during the period 20002012, the service sector contributed increasing shares to gross domestic product (GDP), trade and employment (ibid.).

Moreover, Hidalgo et al. (2007) also suggested that nations grow by upgrading the type of products they produce and export. Upgrading basically tied to the previous level of capabilities. They also indicated that countries diversify their products towards goods close to the current products. Based on this it is possible to suggest that non- 
manufacturing economies (economies like in Africa) diversify their products towards other non-manufacturing outputs in their efforts to exploit their natural resources. On the other hands, unlike the poor nations, the new close product for a rich nation is a more complicated product which requires more capabilities than the existing level of capabilities. Thus, advanced nations are in continuous improvement in their capabilities than the poor nations do.

To make catch up realized in the South, the South needs to "jump" over uncommon distance in the product space. Inability of the South to "jump" infrequently/uncommonly is suggested to be caused by producing non competitive export and failing to converge to the income level of the rich nations (ibid.). With regards to the network of relatedness between products or product space, the most upscale/advanced products are located in densely connected core and lower income products located in less connected Periphery/South (ibid.).

In mirror discussions, the problem related to economic complexity in African seems to prevail in Latin American and Caribbean (LAC) countries as well. Even if economic complexity index of LAC countries was seen soaring from the early 1960s to the early 1990s, it has been worsening ${ }^{33}$ from the late 1990s onward. Unlike LAC and African countries, the economic complexity index of the emerging Asian economies has been kept on soaring from the early 1960s onward (Ding X. and Hadzi-Vaskov M., 2017).

Based on the empirical result of this study, there is unstable equilibrium level of technological intensity due to the positive coefficient of economic complexity index. In other words, the equilibrium point is a saddle point. The functional form of the FE regression result in the table 1 and its equilibrium condition are presented as follows:

$$
\dot{N}=0.375+0.434 N+0.01 G
$$

From equation (17), N stands for economic complexity index (eci) and G or "g" stands for technology gap. Solving equation (17) for $\mathrm{N}$ (given $\dot{N}=0$ ) gives equilibrium level of $\mathrm{N}$ which is presented as follows:

$$
N=\frac{-0.375-0.01 G}{0.434}
$$

From equation (18), for a given value of $\mathrm{G}$, the equilibrium level of $\mathrm{N}$ is some negative number. Moreover, the unstable phase diagram of the equilibrium condition is also presented as follows.

\footnotetext{
33 The economic complexity index is said to be worsening in LAC countries because the share of least complex export products is seen increasing while that of top complex export products is declining over the stated period.
} 
Figure 2: Phase diagram (of the linear LAS technological intensity Model in Africa)

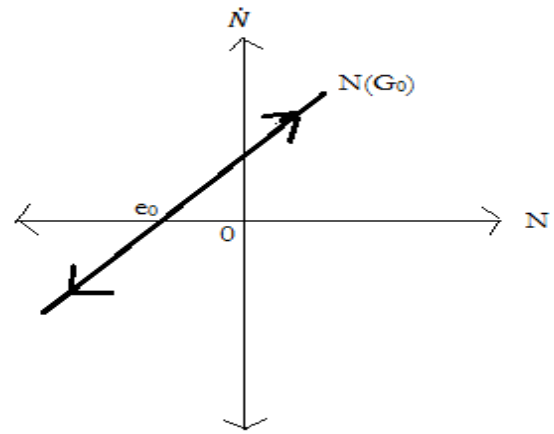

Source: Own illustration based on equation 17 and 18

From figure (2), the upward sloping phase diagram indicates the instability of LAS technological intensity model in Africa due to the positive coefficient of $\mathrm{N}$ (economic complexity index of Africa or $\left.\mathrm{e}_{\mathrm{c}}\right)$. Point $\mathrm{e}_{0}$ on $\mathrm{N}\left(\mathrm{G}_{0}\right)$ phase diagram is the negative equilibrium level of $\mathrm{N}$ for a given level of $\mathrm{G}$ (say it $\mathrm{G}_{0}$ ). Unlike nations in the North, the negative values of the economic complexity indices of most African nations are due to the fact that their economic complexity indices are lower than the world average economic complexity index.

To sum up, unlike the mainstream neo-classical growth models, catch up (convergence) is not manna from the heaven. In other words, African nations could not simply enjoy technology spillovers without deliberate efforts ${ }^{34}$ to learn and apply the knowledge to their respective productive sectors. Among others, provision of all sort of "relevant" infrastructures and subsidies for the development of the manufacturing sector might be crucial as higher level of income is mainly the result of what nations export to the international market. The incomparable high tech natures of products of the North have been being paid absolutely higher prices in the international market. It is this heterogeneous structure that needs to be changed in Africa. Africa has to benefit from technology spillovers via designing "proper" policies and strategies that could allow enhancing capabilities of technological imitation. It is obvious that quick shift to the manufacturing sector dominant economy is not any easy task. However, African nations can have clear and achievable vision backed by "proper" policies, strategies and commitment that could realize manufacturing sector dominant economies within a given possible time frame. This might command exhaustively considering experiences of catching-up economies (which have close social, political and economic characteristics with African nations) elsewhere in the world as it could help the African nations to learn from the failure and the success stories of the best performing economies in their catching-up processes.

\footnotetext{
34 This might include deliberate and strategic government intervention in the process of extracting and applying knowledge.
} 


\section{Conclusions}

This paper surveys the dynamics of product complexity of African nations. To meet this purpose, the LAS technological intensity model is employed. The LAS model is tested in this paper employing the standard panel data regression method on sample of 23 African economies and OECD member economies using the World Bank's database (WDI database) and the OEC (the Observatory of Economic Complexity) database for the period from 1996-2014.

The FE regression result indicates a significant positive relationship between the time derivative of the economic complexity index of Africa (proxy for the time derivative of the technological intensity of Africa) and economic complexity index of Africa (proxy for technological intensity of Africa). This positive relationship could imply that African nations are diversifying their products to towards the technologically less intensive (ubiquitous) and familiar commodities (but different commodities in their kind) that could not challenge their relative labor productivity. Diversifying towards commodities like these might be specialization towards different agricultural outputs, services or natural resources which were not previously known to the respective areas (Africa) or launch to produce and export commodities which were not meant for export previously. This might imply absence of entry cost to the close/neighbor economic activities. This reasoning seems consistent with the report of UNCTAD (2015). Based on the report export specialization in the manufacturing sector in Africa seems to be at its lowest state. Moreover, the finding is consistent with the suggestion of Hidalgo et al. (2007). They suggested that nations grow by upgrading the type of products they produce and export and upgrading is basically tied to the previous level of capabilities.

With regards to the equilibrium level of the economic complexity index, the positive coefficients of the economic complexity index and the per capita GDP imply that the equilibrium point is a saddle point and therefore instability of the LAS technological intensity model in Africa.

To sum up, as Verspagen (1991) indicated, the possibility of catch up is not manna from the heaven if not deliberate and all rounded efforts are not put in place. It is also good to share the idea of UNECA (2013) which proposes Africa should have a dynamic science, technology and innovation (STI) policy. The STI policy of Africa should be assessed in terms of its effects on the position of the manufacturing sector activities as the manufacturing sector is widely accepted for being the most dynamic and productivity enhancing sector of all sectors. In other words, the African STI policy should ensure having a lot of entrepreneurs engaged in wisely identified manufacturing sector activities in the long run that could insure forward and back ward linkages between activities and sectors. Finally, studies on the state and dynamics of technical efficiencies of African economic sectors seem crucial to make future interventions successful.

\section{References}

Acemoglu, D., Antras, P. \& Helpman, E., 2006. Contracts and Technology Adoption. Harvard University. 
Cimoli, M. \& Porcile, G., 2011. Technology, structural change and BOP constrained growth: A structuralist toolbox. p. ECLAC. United Nations.

Ding, X. \& Hadzi-Vaskov, M., 2017. Composition of Trade in Latin America and the Caribbean. IMF Working Paper WP/17/42, March.

Fagerberg, J. \& Godinho, M., 2004. Innovation and Catching-up. s.1.:The Oxford Handbook of Innovation. Oxford: Oxford University Press, 514-544.

Fagerberg, J. \& Srholec, M., 2008. National Innovation Systems, Capabilities and Economic Development. Research Policy, 37, pp. 1417-1435.

Fagerberg, J. \& Verspagen, B., 2002. Technology-Gaps, Innovation-Diffusion and Transformation: An Evolutionary Interpretation. Research Policy, 31 , pp. 1291-1304.

Foster, V. \& Garmendia, C., 2010. African Infrastructure: A time for Transformation. p. World Bank.

Gujarati, D., 2004. Basic Econometrics. s.1.:MacGraw-Hill.

Hausman, J., 1978. Specification Tests in Econometrics. Econometrica, pp. 1251-1271.

Hausmann, R. \& Hidalgo, C., 2010. Country diversification, product ubiquity, and economic divergence. Harvard University, Working Paper No. 201 .

Hausmann, R. \& Klinger, B., 2006. Structural Transformation and Patterns of Comparative Advantage in the Product Space. Harvard University, CID Working Paper No. 128 .

Hausmann, R., Rodríguez, F. \& Wagner, R., 2006. Growth Collapses. Harvard University, CID Working Paper No. 136.

Hausman, R. \& Rodrik, D., 2003. Economic Development as Self-Discovery. Journal of Development Economics,V.72(2), pp. 603-633.

Hidalgo, C. \& Hausmann, R., 2009b. The building blocks of economic complexity. Proceedings of the National Academy of Sciences, 106, pp. 10570-10575.

Hidalgo, C. \& Hausmann, R., 2009. The building blocks of economic complexity. Proceedings of the National Academy of Sciences, 106 (10570-10575) , p. University of Cambridge.

Hidalgo, R., Klinger, B., Barabás, L. \& Hausmann, R., 2007. The Product Space Conditions the Development of Nations.

Hirsch, S., 1968. Location of Industry and International Competitiveness. Operational Research Quarterly, 4, pp. 1953-1969 .

Hummels, D. \& Klenow, P., 2005. THE VARIETY AND QUALITY OF A NATION'S EXPORTS. THE AMERICAN ECONOMIC REVIEW, pp. 704-723.

Kravis, I., 1956. "Availability" and and Othe Influences on the Commodity Composition of Trade. Journal of Political Economy , pp. 143-155.

Kremer, M., 1993. The O-Ring Theory of Economic Development. The Quarterly Journal of Economics, Vol. 108, No. 3, pp. 551-575 .

Krugman, P., 1979. Increasing Returns, Monopolistic Competition and International Trade. Journal of International Economic 9, pp. 469-479.

Melitz, M., 2003. The Impact of Trade on Intra-Industry Reallocations and Aggregate Industry Productivity. Econometrica, Vol 79, pp. 1695-1725.

Posner, M., 1961. International Trade and Technical Change. Oxford University Press .

Rodriguez, A., 2007. Clusters and Comparative Advantage: Implication for Industrial Policy. Journal of Development Economics, pp. 43-57. 
Saviotti, P. \& Frenken, K., 2006. Trade Variety and the Economic Performance of Countries. (DIME Working Package 31.

Saviotti, P., Nesta, L. \& Javaid, M., 2010. Export Variety and the Catching Up of Countries. s.l., s.n.

Schott, P., 2003. ACROSS-PRODUCT VERSUS WITHIN-PRODUCT SPECIALIZATION IN INTERNATIONAL TRADE.

Simoes, A. \& Hidalgo, 2011. Analytical Tool for Understanding the Dynamics of Economic Development. [Online]

Available at: http://atlas.media.mit.edu/en/rankings/country/eci/

Smith, A., 1776. An Inquiry into the Nature and Causes of the Wealth of Nations.

STAN Indicators, O., 2005. DIRECTORATE FOR SCIENCE, TECHNOLOGY AND INDUSTRY, s.l.: OECD.

Thirlwall, A., 2011. The Balance of Payments Constraint as an Explanation of International Growth Rate Differences. PSL Quarterly Review, Vol.64 n.256, pp. 429-438.

UNECA, 2013. Trade Facilitation from an African Perspective, Addis Abeba: United Nations Economic Comission for Africa.

UNECA, 2015. Industrializing through trade, Addis Abeba: United Nations Economics Commission for Africa.

Vernon, R., 1966. International Investment and International Trade in the Product Cycle. Quarterly Journal of Economics 80, pp. 191-207.

Weitzman, M. L., 1998. RECOMBINANT GROWTH. The Quarterly Journal of Economics Vol. CXIII.

Wooldridge, J., 2011. Econometrics. New Delhi: CENGAGE Learning.. s.1.:s.n. 


\section{Appendix: Description of the Data}

Table 2: FE Regression Result

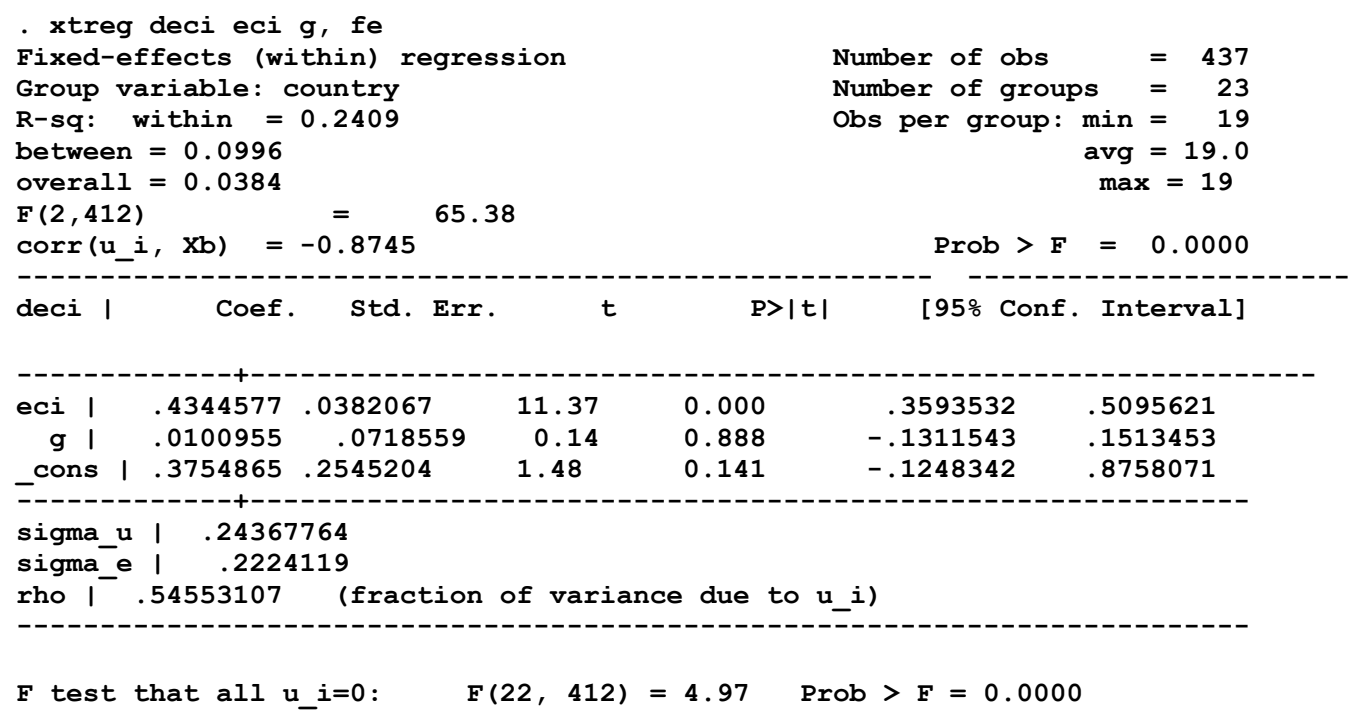

Source: Based on WDI Database (2016) and OEC database (2016)

Table 3: RE Regression Result

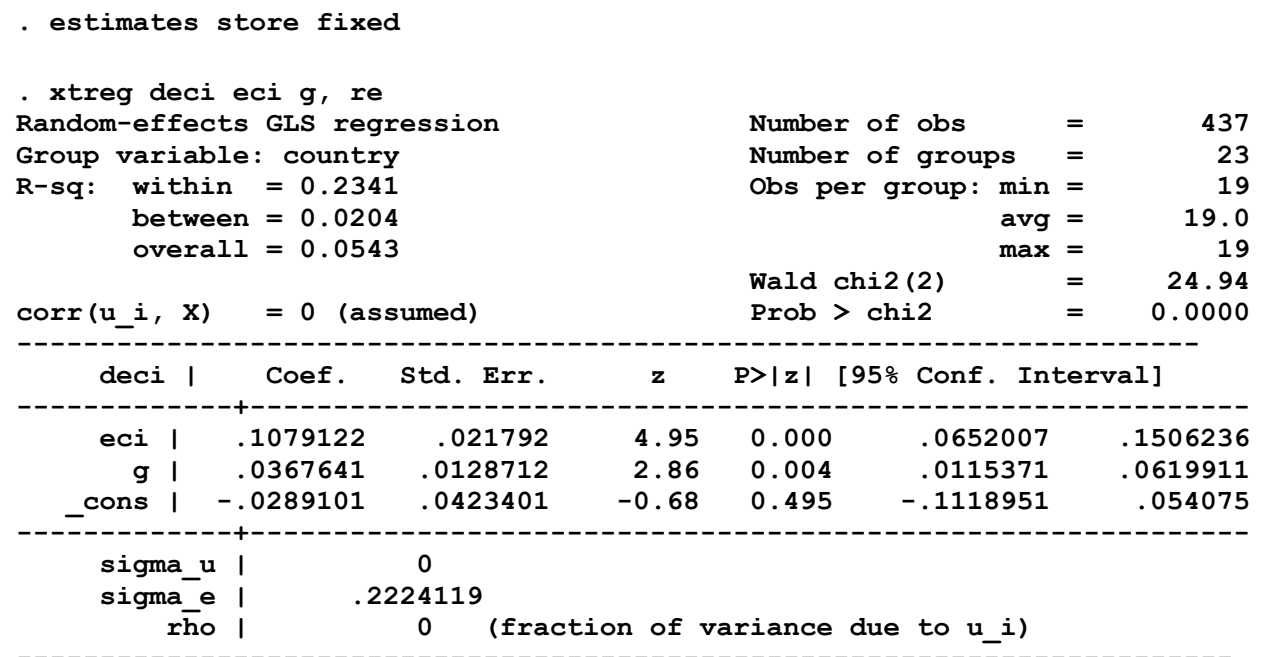

Source: Based on WDI Database (2016) and OEC data base (2016) 
Table 4: Hausman Specification Test

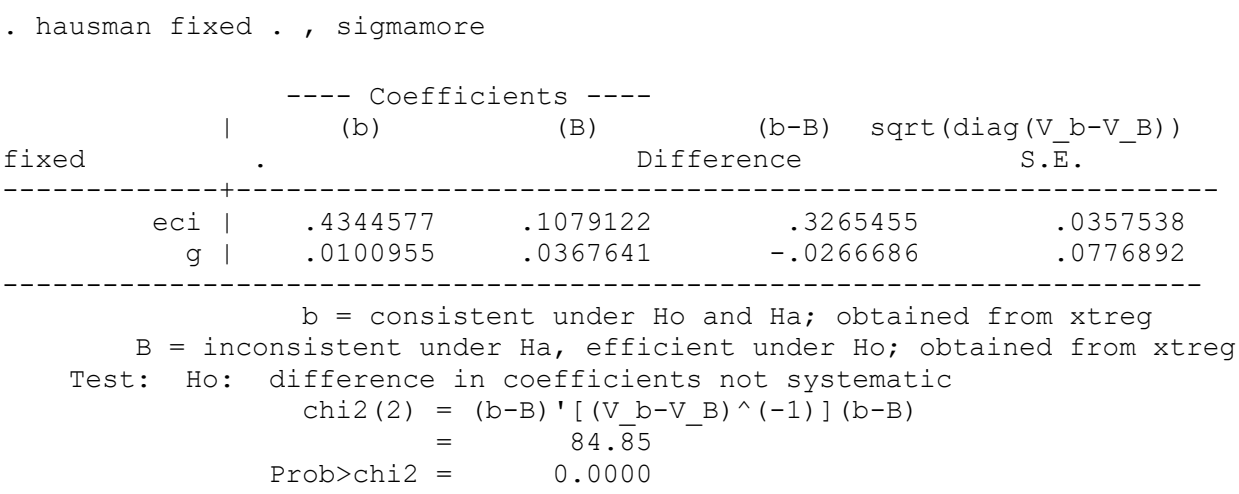

Source: Based on WDI Database (2016) and OEC database (2016)

Table 5: Wooldridge Test for Autocorrelation in Panel Data

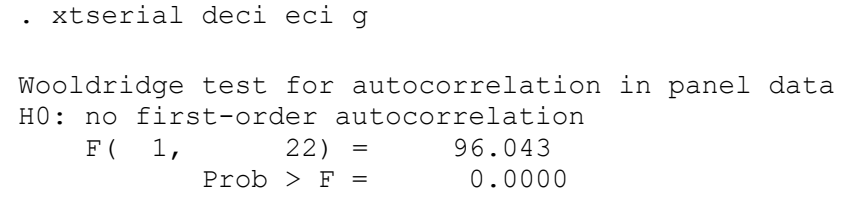

Source: Based on WDI Database (2016) and OEC database (2016)

Table 6: FE Regression Result (with the Robust Driscoll-Kraay standard errors)

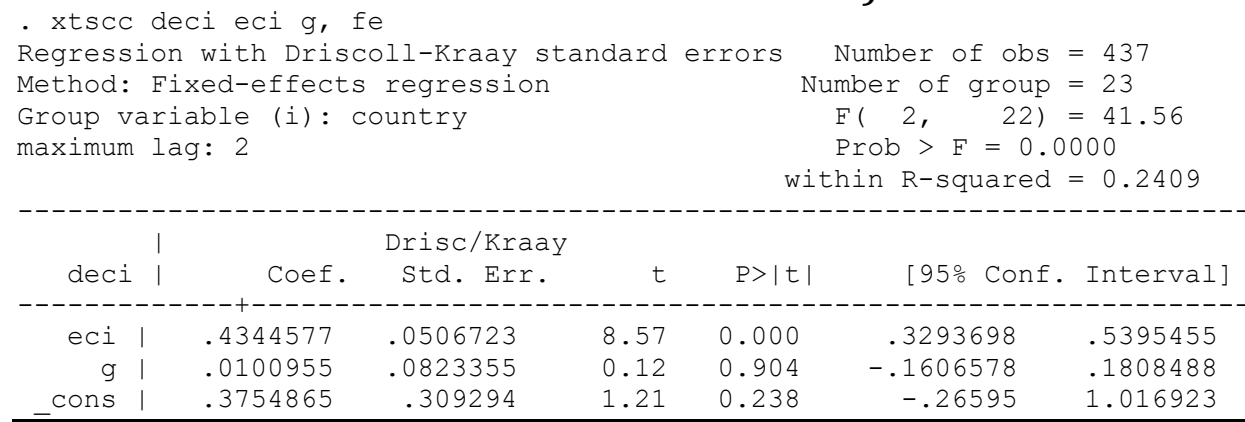

Source: Based on WDI Database (2016) and OEC database (2016) 
Table 7: Pair Wise Correlation Coefficients

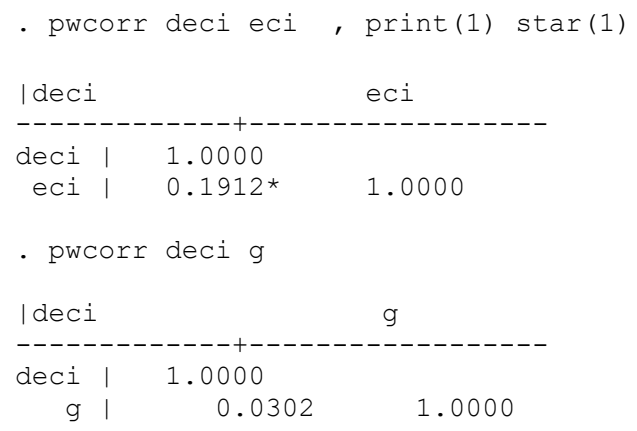

Source: Based on WDI Database (2016) and OEC database (2016)

Table 8: Summary Statistics

\begin{tabular}{|c|c|c|c|c|c|}
\hline Variable | & Obs & Mean & Std. Dev. & $\operatorname{Min}$ & $\operatorname{Max}$ \\
\hline deci | & 437 & -.0001705 & .2500758 & -1.3965 & 1.0301 \\
\hline eci | & 437 & -.9474442 & .6035341 & -2.9184 & .685 \\
\hline 91 & 437 & 3.562725 & 1.021833 & 1.229279 & 5.39085 \\
\hline
\end{tabular}

Source: Based on WDI Database (2016) and OEC database (2016)

Table 9: List of the Sample African Nations

\begin{tabular}{|l|l|}
\hline Algeria & Morocco \\
\hline Cameroon & Mozambique \\
\hline Code ore & Nigeria \\
\hline Egypt & Senegal \\
\hline Ethiopia & South Africa \\
\hline Kenya & Tanzania \\
\hline Libya & Tunisia \\
\hline Madagascar & Uganda \\
\hline Malawi & Yemen \\
\hline Mali & Zambia \\
\hline Mauritania & Zimbabwe \\
\hline Mauritius & \\
\hline
\end{tabular}

